SCIREA Journal of Computer

http://www.scirea.org/journal/Computer

June 21, 2021

Volume 6, Issue 1, February 2021

\title{
Business plan
}

\section{Factor - Contabilidade e Consultoria, Lda.}

Pereira, Adalmiro ${ }^{1}$, Vaz, Ângela ${ }^{2}$, Moreira, Eládio ${ }^{3}$, Mendonça, Hugo ${ }^{3}$, Pacheco, João ${ }^{3}$, Carvalho, Ricardo ${ }^{3}$

${ }^{1}$ Management, ISCAP-PPorto, CEOS member, Porto, Portugal

${ }^{2}$ U. VIGO, PhD student, Vigo, Espanha

${ }^{3}$ Students ISCAP-PPorto, MGO-GP

\begin{abstract}
The purpose of this plan is to foresee and predict the next five years of the company's life and, in this way, to understand how it and the products/services produced by it have evolved over that period of time. With the completion of this work, based on the assumptions, we created a business plan for our company, "4Factor - Contabilidade e Consultoria, Lda.”. A business model was built in which we defined the type of service to be sold, its value, the various prices of suppliers, the expenses with spaces, the hiring of technical and specialized professionals and the acquisition of fundamental machines and software for the operation of the company.

Taking into account the world we live in, where companies and the market are in an increasingly accelerated spiral of competitiveness, it is necessary that there are competent and qualified answers in terms of services. "4Factor - Contabilidade e Consultoria, Lda." it will be a group of accounting offices, whose main area of activity will be accounting.
\end{abstract}


However, we understand that consultancy will also be an area that we should explore, as such, we also intend to provide a financial consultancy service to our clients.

Accounting and consulting are key areas for the survival of the micro-business to the big company. Without these, it is not possible to guarantee correct sustainability and thinking about growth and success for the future. As such, we proposed the creation of a company that provides competent, dedicated and fair-priced service to all its customers.

Keywords: Accounting, investment project, NPV, IRR

\section{Introduction}

Initially, they will open two offices - one in Porto and the other in Lisbon - and the intention is to expand in 2023 to five offices in total, thus increasing their national representation (including on the islands).

The company "4Factor - Contabilidade e Consultoria, Lda." it has its genesis in 2020, by 4 managing partners, and should start by having two employees (both Certified Accountants) in its organization. Over the years and the growth of the customer base, we put the hypothesis of reaching a total of 30 employees in 2025: 21 for the production/operational part, 5 accountants and 4 administrators.

This company's growth projection will still be necessary to increase the proximity to customers. Therefore, it will also be convenient to open more spaces (the five already mentioned), thus ensuring the speed of service and response to customers, as well as the dissemination of the company.

Investments in administrative and digital modernization are also planned over the years, so that there is constant updating of procedures, and the possibility of acquiring a car fleet for a closer and more personalized monitoring of consulting projects.

\section{Mission}

Contribute to the growth of small and medium-sized Portuguese companies and their respective regions, through human and business development. The team is made up of experienced professionals in several transdisciplinary areas and with a high spirit of commitment and dedication. 


\section{Eyesight}

To be a reference in the sector for SMEs and reach two thousand customers in a decade.

\section{Values}

The company's values are based on four pillars:

- Ethics: character towards customers and the society in which it operates

- Transparency: based on compliance with the code of ethics

- Rigor: in the analysis and treatment of proposals and works

- Innovation: looking ahead, challenging our employees and customers

In the following table we also discriminate the different points mentioned above in an analysis SWOT.

Figure 1 SWOT Analysis

\begin{tabular}{l|l} 
Opportunities & Forces \\
\hline - Growing demand for consulting services; & - Strong presence on social networks; \\
- Sharp growth in the number of companies; & - Service "on time"; \\
- Investment and modernization incentives (eg Norte & - Reduced service prices; \\
2020). & $\begin{array}{l}\text {-Differentiated service due to the mix of the two areas } \\
\text { of expertise: accounting and consulting. }\end{array}$ \\
\hline Threats & Weaknesses \\
\hline - Economic crisis caused by Covid-19; & - Low number of employees; \\
- Highly competitive market (an increasing number of & - Reduced customer portfolio. \\
accounting offices and consultants); & \\
-An increasingly high turnover of employees. &
\end{tabular}

Source: Prepared by the authors.

\section{The market}

The profession of an accountant is one of the oldest and most important professions, being mandatory for public limited companies and private companies and also for all self-employed professionals or individual entrepreneurs with a net annual income of more than 200 thousand euros. At the same time, there is a market that is more difficult to quantify, which 
are companies that do not reach 200,000 euros in net annual income, allowing that option to be made by the entrepreneur on the regime he wants (Organized Accounting or Nonorganized Accounting).

It was necessary to understand the needs of the market and understand which areas could be a source of income, while we intend to create a portfolio of clients in different areas of activity and, in this way, minimize the volatility of different activities. In a universe of 1295 $299^{1}$ companies in Portugal in 2018 , there is a forecast to be able to attract 105 customers with Organized Accounting in 2021, less than 1\% of existing customers in the market, increasing this value to a total of 179 customers in 2023 . On the other hand, it is objective of " 4 Factor Contabilidade e Consultoria, Lda." build a portfolio of 195 clients with Unorganized Accounting in 2021, increasing the number of clients in 2023 to 332 . In this way, the company will reach a portfolio of 510 clients at the end of this project.

Knowing the difficulty of attracting new clients in this area, it was decided that "4Factor Contabilidade e Consultoria, Lda." will, simultaneously, intervene in the area of consultancy. With this service, the organization intends to demonstrate its professionalism and competence and, in this way, obtain new clients.

The market over the last few years has been subject to changes and constant changes, the Accountants and consequently the Accounting Offices, have been able to resist the constant legislative changes and the different economic crises. Faced with the changes and difficulties existing today, it is necessary to adapt, reinvent and appeal to creativity in order to survive.

\subsection{Business partners}

A market study was carried out, and it was found that there is a market niche with a huge scope for growth and potential. The existence of companies with branches, distributed throughout the national territory, has a need for an immediate response to many accounting issues. "4Factor - Contabilidade e Consultoria, Lda." it will be a group of Accounting Offices, with a national distribution and with representation, in an initial phase, in the two biggest Portuguese cities.

With this operating model, it is intended that customers become commercial partners and, in this way, make the company's work reach the entire public, which would not normally be reached.

\footnotetext{
${ }^{1}$ Data removed - By date on 10/01/2021
} 
"4Factor - Contabilidade e Consultoria, Lda." it intends to be for partners the place where they can find, in one place, everything they are looking for, without having to worry about researching other companies and professionals on their own.

\subsection{Competitors}

In 2018, there were 10,482 companies on the market ${ }^{2}$ with the CAE in Accounting and Auditing Activities; Tax Consulting (CAE 69200) and 13210 companies with the CAE in other business and management consulting activities (CAE 70220). These companies are distributed $17.3 \%$ in the metropolitan area of Porto and $52.7 \%$ in the metropolitan area of Lisbon for CAE 70220. In relation to CAE 69200, companies located in the metropolitan area of Lisbon make up $32 \%$ of the total number of companies and $19 \%$ in the Porto metropolitan area.

Although there is a large number of companies, it appears that by dividing the total value of companies by each office, one reaches 123 companies for each existing office.

\subsection{Other external entities}

The activity that "4Factor - Contabilidade e Consultoria, Lda." will exercise is dependent on different external entities. The accounting area has the benefit of being legislated, obliging companies with a turnover of more than 200 thousand euros to have an accountant, but on the other hand, it depends on the legislation from the previous entities described. The accounting records will have to comply with the law and cannot be done differently for each client, or in a way that, at a given time, it fits better.

There is also the Order of Certified Accountants (OCC), an entity which involves a record and which tries to parameterize the functioning of the area, thus ensuring a more transversal procedure for all associates.

And finally, we have to consider the Entities such as the Order of Notaries, which together with the Ministry of Justice regulates the notarial activity, an entity that will be necessary for the different business registrations and necessary for our clients.

\subsection{Services}

The services that "4Factor - Contabilidade e Consultoria, Lda." it will essentially have two areas of intervention, Accounting and its registration, as well as the provision of all necessary documents so that customers can grow with the organization. A regular analysis of the

\footnotetext{
${ }^{2}$ Data taken: Bank of Portugal Sector Tables (accessed January 2021)
} 
company's economic-financial position and evolution will be carried out (cost structure, economic ratios, financiais ratios, financial difficulties forecasters, etc.). There will be a Consultancy area, where the different needs of customers will be taken into account through detailed diagnoses, identifying the areas to be improved and perfected. Subsequently, the best solutions will be evaluated and suggested to the client, supporting their implementation.

At "4Factor - Contabilidade e Consultoria, Lda." services are offered that are better adapted to the reality of each company, seeking that the customer obtains the best solution depending on the case:

$\checkmark \quad$ Organized Accounting;

$\checkmark \quad$ Non-Organized Accounting (simplified regime);

$\checkmark \quad$ Filling in the model 3 (IRS);

$\checkmark \quad$ Consultancy.

sale prices

Figure 2 Services Prices

\begin{tabular}{lc} 
Service & Value \\
Organized accounting & 300.00 euros \\
\hline Unorganized accounting (simplified regime) & 80.00 euros \\
\hline Filling in template 3 (IRS) & 20.00 euros \\
\hline Consultancy & 500.00 euros \\
\hline
\end{tabular}

Source: Prepared by the authors.

sales in value ${ }^{3}$

Figure 3 Volume of business

\begin{tabular}{|l|l|l|l|l|l|l|}
\hline SERVICE PROVISIONS - NATIONAL MARKET & $\mathbf{2 0 2 0}$ & $\mathbf{2 0 2 1}$ & $\mathbf{2 0 2 2}$ & $\mathbf{2 0 2 3}$ & $\mathbf{2 0 2 4}$ & $\mathbf{2 0 2 5}$ \\
\hline Unorganized Accounting & 187200 & 196560 & 275184 & 295823 & 325405 \\
\hline Growth rate & & $5.00 \%$ & $40.00 \%$ & $7.50 \%$ & $10.00 \%$ \\
\hline Organized Accounting & 378,000 & 396900 & 555660 & 597335 & 657068 \\
\hline Growth rate & & $5.00 \%$ & $40.00 \%$ & $7.50 \%$ & $10.00 \%$ \\
\hline Model 3 - IRS & 20000 & 21500 & 70000 & 77000 & 84700 \\
\hline Growth rate & & $7.50 \%$ & $225.58 \%$ & $10.00 \%$ & $10.00 \%$ \\
\hline
\end{tabular}

\footnotetext{
${ }^{3}$ Table taken from Finicia file
} 


\begin{tabular}{|l|l|l|l|l|l|l|l|}
\hline Consultancy & & 6000 & 6300 & 9450 & 10159 & 10921 \\
\hline Growth rate & & & $5.00 \%$ & $50.00 \%$ & $7.50 \%$ & $7.50 \%$ \\
\hline TOTAL & $\mathbf{0}$ & $\mathbf{5 9 1 2 0 0}$ & $\mathbf{6 2 1} \mathbf{2 6 0}$ & $\mathbf{9 1 0} 294$ & $\mathbf{9 8 0 3 1 6}$ & $\mathbf{1 0 7 8 0 9 4}$ \\
\hline \hline
\end{tabular}

Source: Prepared by the authors.

\section{Projections assumptions and their justification}

\subsection{Operational activity}

\subsubsection{Personnel expenses}

"4Factor - Contabilidade e Consultoria, Lda" has high personnel costs as a result of the high number of employees.

In addition to the 4 administrators, the entity has 2 Account workers - in 2020 - the year of the entity's registration - for handling bureaucracy and organizing work models. We expect with these 6 workers in 2020, in the month of operation, to spend a total of $€ 11,550$, with all salaries and other mandatory expenses that the company has to pay.

In 2021, the entity hires 12 operational employees divided by the two work establishments Porto and Lisbon - totaling 18 employees.

From 2021 onwards, with the 18 employees, in the fiscal year, we expect to spend a total of $€ 303,601$, with a 3\% increase in the salaries of our employees in 2022.

With the acquisition of new work spaces, the entity recruited 12 new workers, including 3 Account Workers and 9 operational. Based on the increase in the number of workers and a $3 \%$ increase in salaries, personnel expenses amounted to €506 419 in 2023, and in the following years 2024 and 2025, there were percentage increases of 3\% in the value. of the same.

Figure 4 Summary table

\begin{tabular}{|l|l|l|l|l|l|l|l|}
\hline \begin{tabular}{l} 
SUMMARY TABLE \\
\hline Remunerations
\end{tabular} & $\mathbf{2 0 2 0}$ & $\mathbf{2 0 2 1}$ & $\mathbf{2 0 2 2}$ & $\mathbf{2 0 2 3}$ & $\mathbf{2 0 2 4}$ & $\mathbf{2 0 2 5}$ \\
\hline $\begin{array}{l}\text { Social entities } \\
\text { Personal }\end{array}$ & 7000 & 86520 & 89116 & 91789 & 94543 & 97379 \\
\hline Charges on remuneration & 2,333 & 158620 & 163379 & 317439 & 326963 & 336771 \\
\hline
\end{tabular}




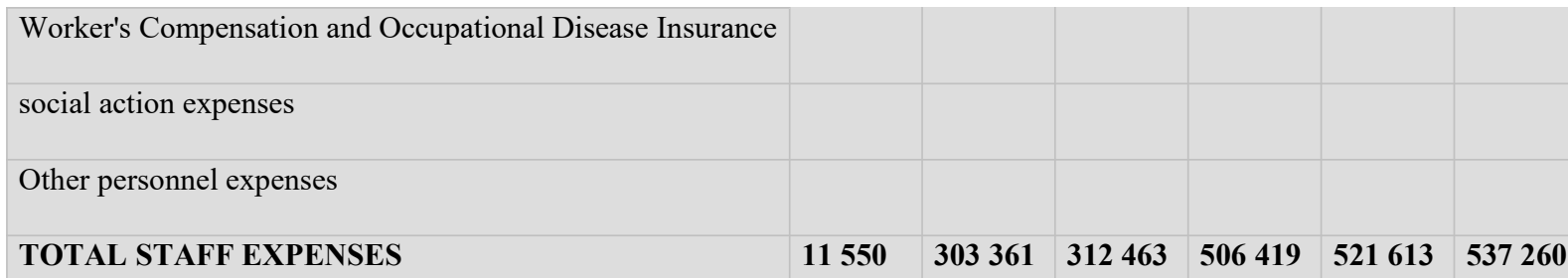

Source: Prepared by the authors.

\subsubsection{Supplies and external services}

In our plan, we also address the estimated costs that we will have with external supply and services inherent to our activity.

There are several operating costs that the company resorts to on a monthly basis for its proper functioning, such as electricity, office supplies and communication services (mobile phones, internet), essential programs for operational activity (CRM, Office 365, MDI) to administrative services, daily utility resources for all employees such as water, hygiene expenses and travel and accommodation. Advertising, litigation and notary fees and expenses are other expenses included in this item.

Taking all this into account, the value of external supply and services planned for the year 2020 would be approximately $€ 5,661$, however, in this first year the company was only open for 1 month.

In the remaining years, as the company had been in business for a year (12 months), the total value of these services would be $€ 93526.20$ in 2021, and in 2022 there is a slight increase in our FSE expenses compared to updating the rents.

Already in 2023, there is a huge increase in expenditure on ESF as a result of the introduction of new work spaces totaling $€ 211,183.37$. In the following years - 2024 and 2025 expenditure on FSE suffers a slight increase due to the updating of rents.

\subsubsection{1. $\quad$ Working Capital Needs (NFM)}

The Working Capital Needs (when positive) translate into the need for financing arising from the exploration cycle - that is, throughout the operation, if the credits contracted, resulting from the operational activity (Supplier account, for example) - Cyclic Resources ; are not enough to settle the operating credits granted (Customer account, for example) - Cyclic Needs; ideally, it will be necessary to guarantee a financial cushion capable of covering this difference - Investment in Working Capital. 
Thus, and as a result of the assumptions made in the Business Plan, it is expected that the Cyclic Needs - in this case in particular the Customer account, will increase over the years in the same proportion as the Turnover, assuming at the end of 2025 a value of $€ 110,505$, with special emphasis on the highest year-on-year growth in 2023. This includes the opening of 3 new offices (also naturally increasing the customer base).

With regard to Cyclic Resources, it is expected that the accounts that comprise them will behave in a manner similar to the evolution of turnover, namely the Suppliers account and the one for liabilities with the State and Other Public Entities. As a result, once again, of the establishment of 3 new offices, the greatest relative growth is verified in 2023. On the other hand, the liabilities for delivering Value Added Tax represent the main liability account of Cyclic Resources.

\subsection{Investment activity and its financing}

\subsubsection{Investment map}

As for the Investment Plan, there are two key moments in terms of investment in 4Factor Contabilidade e Consultoria, Lda.: it will be the initial investment - $€ 61,600$, which coincides with the acquisition of the first Tangible Fixed Assets necessary for start the organization's activity - namely, Basic Equipment (computers, and printers), Transport Equipment (1 Vehicle per Office) and Administrative Equipment (Furniture, Chairs, etc.), and in 2023, when it is intended to expand the geographical area covered by the company, with the opening of offices in the Algarve, Madeira and Azores, for which it will be necessary to invest again in the acquisition of Tangible Fixed Assets (similar to that made in the first investment in Non-Current Assets) that sustain the growth of the company's activity, amounting to $74400 €$.

\subsubsection{2. $\quad$ Financing Map}

Regarding the financing necessary to invest in the Assets and to finance the Exploration Cycle, the company will count on the investment of the four partners in the Share Capital of 4Factor - Contabilidade e Consultoria, Lda. as detailed below:

- $\quad$ Eladio Joel Moreira: $€ 25$ 000.00;

- $\quad$ Hugo Castro Mendonça: $€ 25$ 000.00;

- João Rafael Pacheco: $€ 25$ 000.00;

- $\quad$ Ricardo Carvalho: $€ 25,000.00$. 
In addition to the initial value relating to Share Capital, it is expected that the exploration cycle will provide net financial resources, meaning Net/Retained Earnings.

\subsection{Ratios}

The analysis of the business plan of "4Factor - Contabilidade e Consultoria, Lda." and its main financial ratios.

In particular, the General Liquidity always assumes values greater than 1, thus it can be concluded that the company has, certainly, the capacity to assume all short-term liabilities, with margin to face any mismatch between the period of payment of the liabilities and the term for realization of assets.

Moving on to the long-term perspective, the Financial Structure, Debt Structure and Solvency ratios were considered, in order to better understand, from a financial point of view, the company's profile.

The debt ratio and financial structure establish a ratio between the organization's Liabilities and Equity. Figure 5 shows a decreasing trend in the value of this ratio, having been higher than 1 since 2020, the year in which "4Factor - Contabilidade e Consultoria, Lda." in 2020 until 2025. It can be seen that the value in 2021 will be $40 \%$, which translates into a high indebtedness, but that it progressively decreases to $18 \%$ in 2025 .

Indebtedness and Financial Structure

Figure 5 Debt Ratio and Financial Structure

\begin{tabular}{llllll} 
& $\mathbf{2 0 2 1}$ & $\mathbf{2 0 2 2}$ & $\mathbf{2 0 2 3}$ & $\mathbf{2 0 2 4}$ & $\mathbf{2 0 2 5}$ \\
Passive & 85027.00 & 96777.00 & 113369.00 & 133550.00 & 160682.00 \\
\hline Equity & 207905.00 & 345082.00 & 453636.00 & 601522.00 & 812409.00 \\
\hline ratio & $\mathbf{4 1 \%}$ & $\mathbf{2 8 \%}$ & $\mathbf{2 5 \%}$ & $\mathbf{2 2 \%}$ & $\mathbf{2 0 \%}$ \\
\hline
\end{tabular}

Source: Prepared by the authors.

Completing the analysis of the debt ratio and financial structure, attention should be paid to the Debt Structure ratio, which will measure the composition of the company's liabilities in terms of maturity.

In an opposite perspective to the Financial Structure ratio, the Solvency ratio establishes a proportional relationship between Equity and Liabilities. Naturally, and in line with what was seen in the first, the Solvency ratio shows an increasing trend, reaching in 2025 more than 
twice the value in 2021, thus verifying a greater dependence of the company on outside capital - figure 6.

Solvency

Figure 6 Solvency Ratio

\begin{tabular}{llllll} 
& $\mathbf{2 0 2 1}$ & $\mathbf{2 0 2 2}$ & $\mathbf{2 0 2 3}$ & $\mathbf{2 0 2 4}$ & $\mathbf{2 0 2 5}$ \\
\cline { 2 - 6 } Passive & 207905.00 & 345082.00 & 453636.00 & 601522.00 & 812409.00 \\
\hline Equity & 85027.00 & 96777.00 & 113369.00 & 133550.00 & 160682.00 \\
\hline ratio & $\mathbf{2 4 5 \%}$ & $\mathbf{3 5 7 \%}$ & $\mathbf{4 0 0 \%}$ & $\mathbf{4 5 0 \%}$ & $\mathbf{5 0 6 \%}$
\end{tabular}

Source: Prepared by the authors.

Given the fact that Equity is positive, the scenario of technical bankruptcy is clearly far away, as shown by the values always above 1 in the Total Solvency ratio shown in Figure 7.

Total Solvency

Figure 7 Total Solvency Ratio

\begin{tabular}{llllll} 
& $\mathbf{2 0 2 1}$ & $\mathbf{2 0 2 2}$ & $\mathbf{2 0 2 3}$ & $\mathbf{2 0 2 4}$ & $\mathbf{2 0 2 5}$ \\
\cline { 2 - 6 } Active & 292932.00 & 441859.00 & 567005.00 & 735072.00 & 973091.00 \\
\hline Passive & 207905.00 & 345082.00 & 453636.00 & 601522.00 & 812409.00 \\
\hline ratio & $\mathbf{1 4 1 \%}$ & $\mathbf{1 2 8 \%}$ & $\mathbf{1 2 5 \%}$ & $\mathbf{1 2 2 \%}$ & $\mathbf{1 2 0 \%}$
\end{tabular}

Source: Prepared by the authors.

Complementing the analysis of "4Factor - Contabilidade e Consultoria, Lda.", it is important to analyze the Financial Autonomy ratio, which identifies the fraction of Assets that is composed of Equity, that is, the company's independence (or dependence) on capital aliens.

Financial autonomy

Figure 8 Financial Autonomy Ratio

\begin{tabular}{llllll} 
& $\mathbf{2 0 2 1}$ & $\mathbf{2 0 2 2}$ & $\mathbf{2 0 2 3}$ & $\mathbf{2 0 2 4}$ & $\mathbf{2 0 2 5}$ \\
\hline Equity & 207905.00 & 345082.00 & 453636.00 & 601522.00 & 812409.00 \\
\hline Active & 292932.00 & 441859.00 & 567005.00 & 735072.00 & 973091.00 \\
\hline ratio & $\mathbf{7 1 \%}$ & $\mathbf{7 8 \%}$ & $\mathbf{8 0 \%}$ & $\mathbf{8 2 \%}$ & $\mathbf{8 3 \%}$ \\
\hline
\end{tabular}

Source: Prepared by the authors.

In this case, and as it is possible to infer from the analysis of the previous ratios, the Financial Autonomy shows an increasing trend in the period under analysis. In the same sense, the 
figures calculated show that "4Factor - Contabilidade e Consultoria, Lda." holds sufficient Equity to ensure its Total Liabilities.

\subsection{Cash flows}

"Working capital needs are related to Turnover. As the Business Volume increases (a growing company), the working capital needs will tend to increase”. (Sá e Silva, 2016, p.96)

The term "cash-flow" translates to "cash flow" - and the evolution of this indicator allows us to know how an organization's cash flow is behaving, that is, it reflects the company's cash inflows and outflows, in each period of the activity.

Through cash-flow, it is possible to identify the extent to which the company's structure has the financial availability to ensure its responsibilities, meet monthly obligations and keep up and running.

Based on the period under analysis (2020-2025), and as can be seen in Figure 9, we can conclude that the Accumulated Cash Flow, although starting with a negative value (opening of the first two establishments), increases over the five subsequent periods . However, in 2023 there is a slowdown in this growth, coinciding with the investment in the opening of offices in the Algarve, and the Archipelagos of the Azores and Madeira, with a total value of $€ 657,566$ in the last year.

Figure 9 Post-Financing Project Perspective

\begin{tabular}{|l|l|l|l|l|l|l|l|}
\hline From the perspective of the Post-Financing Project & 2020 & 2021 & 2022 & 2023 & 2024 & 2025 & 2026
\end{tabular}

\begin{tabular}{|l|l|l|l|l|l|l|l|l|}
\hline Free Cash Flow to Firm & $\mathbf{- 7 7 2 0 9}$ & $\mathbf{1 2 4} 049$ & $\mathbf{1 4 8} 163$ & $\mathbf{5 8} 036$ & $\mathbf{1 7 5} 154$ & $\mathbf{2 2 9} 372$ & $\mathbf{5 2} 910$ \\
\hline & & & & & & & & \\
\hline WACC & $0.60 \%$ & $0.60 \%$ & $0.60 \%$ & $0.60 \%$ & $0.60 \%$ & $0.60 \%$ & $0.60 \%$ \\
\hline update factor & 1 & 1,006 & 1,012 & 1,018 & 1,024 & 1,030 & - \\
\hline
\end{tabular}




\subsection{Rating criteria}

Net Updated Value

Net Updated Value (NPV) of the Investment Project - in this case, the Business Plan, translate in the sum of the updated values (by the update rate - Weighted Average Cost of Capital (WACC)) of all Free Cash Flows (FCF), which, as explained above, represent cash inflows in the organization net of cash outflows :

$$
\begin{gathered}
N P V=\sum_{i=0}^{n}\left(\frac{F C F_{i}}{(1+W A C C)^{i}}\right) \\
=>N P V=-77209+123310+146401+57004+171013+222613+51530 \leq \\
<=>N P V=694482 €
\end{gathered}
$$

Given that the calculated value is clearly above zero, the investment in this Business Plan is expected to produce profit for investors - in the absence of a "more profitable" investment, and looking only at this indicator, it will make sense to invest in this project .

\section{Internal Rate of Return}

The Internal Profitability Rate will translate into the rate at which the capital remaining in the project is applied - it should be understood that it will be the rate associated with the Free Cash Flows update factor that will equal the VAL to zero:

$$
N P V=\sum_{i=0}^{n}\left(\frac{F C F_{i}}{(1+I R R)^{i}}\right): \exists I R R, N P V=0
$$

The IRR obtained by an automated iterative method performed in Excel is $163.45 \%$. Thus, and (again) not having alternative investment projects, with an IRR value (a lot) higher than wacc, it is advisable to invest in this project.

\section{Profitability Index}

The Profitability Index is an indicator of investment projects that, when relating the sum of the updated values of the Free Cash Flows with the sum of the updated values of the Investment Cash Flows, measures the return on the investment, that is, it indicates the return obtained by every euro invested: 


$$
P I=\frac{\sum_{i=0}^{n}\left(\frac{F C F_{i}}{(1+W A C C)^{i}}\right)}{\left|\sum_{i=0}^{n}\left(\frac{C F I_{i}}{(1+W A C C)^{i}}\right)\right|}=>P I=\frac{694481,89}{|-134676,71|}<=>P I=5,16 € / € . \text { invest }
$$

Due to the fact that the calculated amount of income tax is greater than 1, more specifically $€ 5.16 / €$ invested, we can then say that it is advantageous to invest in this project since for every euro invested, the company receives around 5.16 euros .

Investment Recovery Period (pay-back period - PBP)

The Investment Recovery Period (or Pay Back Period) reflects the time it takes to recoup the initial capital investment through the investment project's FCFs, thus including the respective risk premium:

$$
\begin{gathered}
P B P=t+\frac{\sum_{i=0}^{t}\left(\frac{F C F_{i}}{(1+W A C C)^{i}}\right)}{\left(\frac{F C F_{i}}{(1+W A C C)^{t+1}}\right)}=>P B P=1+\frac{46101}{123310}<=>P B P=1+0,3739 \\
0,3739 \text { years }=0,3739 * 12 \text { months }=4,5 \text { months } \\
P B P=1 \text { year } * \text { and 4,5 months }
\end{gathered}
$$

Thus, according to the PRI calculated for 1 year* and 4.5 months, it is expected that during the fifth month of the second period of activity, the initial investment in capital will already be recovered, including the respective risk premium.

*Note that the first year of activity corresponded to only 1 month of operation.

Since the project lifetime is 5 years or more, and the PRI is less than that period, without alternative investment projects, from the investor's point of view, it makes sense to bet on this project.

Annual Equivalent Benefit (AEB)

Assume that there is a financial instrument corresponding to an annual fixed income in arrears with a duration equal to the periods considered in the NPV of our investment project/business plan ( 6 periods), which will be equivalent to the NPV of the project - the value of The fixed income of said financial instrument will thus be the Annual Equivalent Benefit (AEB). 


$$
\begin{gathered}
A E B=\frac{N P V}{\frac{1-(1+W A C C)^{-n}}{W A C C}}=>A E B=\frac{694481,89}{\frac{1-(1+0,6 \%)^{-6}}{0,6 \%}} \leq> \\
<=>A E B=118189,79 €
\end{gathered}
$$

In this sense, the amount of $€ 118189.79$ obtained in the calculation of the AEB represents the value of a fixed income, in arrears, which will be extended for a period of 6 years, with a current value of the instrument equal to $€ 694481.89$.

Other evaluation criteria - Economic Value Added (EVA)

The (EVA) or Economic Profit is a measure based on the Residual Income technique that serves as an indicator of the profitability of the projects carried out. Its basic assumption is the idea that real profit occurs when additional wealth is created for shareholders and that projects must generate returns above their cost of capital.

EVA takes almost the same form as residual income and can be expressed as follows:

$$
E V A=N O P A T-(W A C C-\text { Capital Invested })
$$

\subsection{Sensitivity analysis}

\subsubsection{Critical Point (Pc)}

Figure 10 Critical point

\begin{tabular}{|l|l|l|l|l|l|l|}
\hline & $\mathbf{2 0 2 0}$ & $\mathbf{2 0 2 1}$ & $\mathbf{2 0 2 2}$ & $\mathbf{2 0 2 3}$ & $\mathbf{2 0 2 4}$ & $\mathbf{2 0 2 5}$ \\
\hline sales and services & & 591200.00 & 621260.00 & 910293.98 & 980316.03 & $1,078,093.66$ \\
\hline Variation in production inventories & & & & & & \\
\hline Cost of Sales & & & & & & \\
\hline ESF Variables & 400.00 & 37980.00 & 37980.00 & 93800.00 & 93800.00 & 93800.00 \\
\hline Gross Contribution Margin & $\mathbf{- 4 0 0 . 0 0}$ & $\mathbf{5 5 3 2 2 0 . 0 0}$ & $\mathbf{5 8 3 2 8 0 . 0 0}$ & $\mathbf{8 1 6 ~ 4 9 3 . 9 8}$ & $\mathbf{8 8 6 5 1 6 . 0 3}$ & $\mathbf{9 8 4} 293.66$ \\
\hline Critical point & & $\mathbf{4 0 1 7 7 5 . 7 1}$ & $\mathbf{4 1 0} \mathbf{1 6 9 . 4 4}$ & $\mathbf{7 2 3} 961.44$ & $\mathbf{7 3 5 ~ 6 0 5 . 0 8}$ & $\mathbf{7 4 1 ~ 0 6 6 . 0 1}$ \\
\hline
\end{tabular}

Source: Prepared by the authors. 


\section{Critical point calculation:}

\section{Pc $=($ ESF Fixed + Expenses with Personnel+Provisions+Dep/Amort+ANC Impairment)/(GCM/Sales and services)}

Having calculated the critical point for the different years of activity, we are given the minimum amount necessary to cover the fixed and variable costs of each year (current earnings).

We verified that the value of "4Factor - Contabilidade e Consultoria, Lda." that the critical point of our company is high, increasing the risk of reaching it and, therefore, losing money.

\section{Conclusion}

In a first approach, we start by preparing a strategic plan for "4Factor - Contabilidade e Consultoria, Lda." based on initial strategic thinking. It was essential to study the business area and the internal and external conditions that an accounting and consulting company faces during its activity.

Having defined the assumptions and forecasts for the business plan, the Financial Statements of the entity for 6 consecutive years (2020, 2021, 2022, 2023, 2024 and 2025) were analyzed in order to perceive the financial and economic "health" of the organization. In this aspect, it is considered that the entity is in Financial Equilibrium since the Working Capital is greater than the Working Capital Needs in the second year of activity of "4Factor - Contabilidade e Consultoria, Lda.", that is, if a positive Net Treasury.

Afterwards, the business idea was evaluated as an investment project. Analyzing indicators such as WACC, NPV, IRR, PBP, PI and AEB, as criteria for evaluating investment projects, allowed us to perceive how interesting this business idea (following the stipulated assumptions and forecasts) would be as an investment - and, in fact, it turned out to be an admittedly profitable business idea.

In short, it is possible to state that throughout this report we were able to meet the requested objectives. This work was also very useful for a better understanding and consolidation of the material taught in a practical approach. 


\section{Bibliography}

Eduardo Sá e Silva (2016). Introduction to Finance: Analysis of working capital financial flows and financial balance, financing strategies. Porto: Editora Vida Económica

Queirós, M., Mota, C., Sá e Silva, E., Pereira, A., Resende, M. (2020). Investment Projects:

Conventional Assessment. Porto: Quântica Editora - Specialized Contents, Ltd. 